\title{
THE LINGUISTIC LACUNICON: COGNITIVE MAPPING IN SCHEMES AND TERMS
}

\author{
Tetiana Anokhina \\ anokhina_mail@yahoo.com \\ Kyiv National Linguistic University, Ukraine

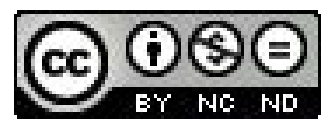

\begin{abstract}
The new linguistic science lacunology has come into prominence recently. The lacunae studies embrace sociolinguistics, nonverbal semiotics and applied linguistics studies. The research of terms of lacunology (lacunicon) is devoted to empty places in the structure of the contrasting languages and the ways of zero verbalization in the written and oral discourse. The empty category of the category "lacunarity" has been studied by the Canadian translators Jean Paul Vinay (1910-1999) and Jean Darbelnet (1904-1990), the Russian pioneers of lacunology Yuriy Sorokin (1936-2009) and Gulchera Bikova and their followers. The research has resulted in the cognitive mind mapping. It turned out that lacunarity has several vectors, e.g. lacunae of language (i), lacunae of speech (ii), lacunae of cognition (iii) to be further discussed in the article. The basic terms of lacunicon are described. These are a pause in syntagmatics, a linguistic gap in paradigmatics, a lacuna in both diachronic and synchronic regimes.
\end{abstract}

Key words: lacunology, lacunicon, gaps, lacunae of language, lacunae of speech, lacunae of cognition.

\section{INTRODUCTION}

Some elements of culture can be barely rendered from one language into another. The difficulties of translation are caused by vague or unclear elements, known as "zero equivalents", lacunae, or gaps. The lacunology as lacunae theory is a young science with challenging of describing and analysing lacunae in the international dimension. The aim of this article is to discuss and illustrate what was done by linguists to initiate a worldview of the linguistic terminology of lacunology. The new linguistic discipline "lacunology" has been designed to deal with lacunae of language, speech and cognition. Lacunae are qualified as the interlinguistic mirror of "cultural specifics".

\section{THE ONTOLOGY OF LACUNICON: FROM LACONIA TO LACUNA}

The modern linguistics, translation studies and nonverbal semiotics have given birth to a new science that is now gaining popularity - the lacunology, a science which studies pauses in speech, cultural and linguistic gaps (Schröder, 1995, p. 10). The expansion of various methods and disciplines interrelating resulted 
in the development of post-structural linguistics where the verbal and nonverbal linguistics are related and friendly sciences for the Lacunae Theorie (Panasiuk, 2007, p. 219).

How was the term of lacunology created? The origin of the word is from ancient Greece: Lacedaemonius, Lakedaimonios, or Lakedaimon is an ancient Greek name for Sparta (Webster New World Dictionary, 1988, p. 753). There was a Lakodomanian place near waters in Greece, where the laconian people lived (from lat. Lacōnicus, Spartan < gk. Lakōnikos < Lakōn, a Spartan (the reputations of the Spartans for brevity of speech) (American heritage college dictionary, 1993, p. 758). The meaning "brief or terse in speech or expression" for the word "laconic" was acquired later (Webster NWD, 1988, p. 754). The meaning "reduction" as lacunarity appeared from "reducing words", "making shorter sentences", "compressing the utterance". The semantic vector of "reduction" was acquired later after reconsideration of the word with the meaning "laconic brevity", " clarity wording" derived form of Greek Spartans from Laconinia, an ancient region of Spartan Greece (The American heritage college dictionary, 1993, p. 758). The word "laconic" is derived from the name of the region by analogy - to speak in a concise way, as the Spartans were reputed to do by the Athenians. Also, the term "laconian" is broadly used in the archaeology and in the history of Greece (Walker \& Cavanagh, 1995, p. 27).

The family of lacuna etymons comprises words with the lac-morpheme and other later derivatives. The lacuna etymon has such close cognates as: lake, laconic, lacuna and near cognates lace, lactation, liquorice, laguna, and liquor which are correspondely lac-, liq-, lag- morphemes. The meaning of those cognates is very close to such notions as (i) liquid (lake, river, water, milk), (ii) lacuna (hole, gap, reduction, shortening, compression), lack of something (defect of manuscript, misunderstanding, absence).

The words are lexical and semantic derivates, the changes caused by the historical replacement (e.g. lacuna < laguna), deletion (e.g. lacuna< lack), or epenthesis (e.g. black).

In the figure below (visual thesaurus.com) lacuna corresponds to (i) proper gaps (coffer, caisson) and to (ii) the rethought secondary meaning of lacuna (blank).

Fig. 1. Lacuna meanings.
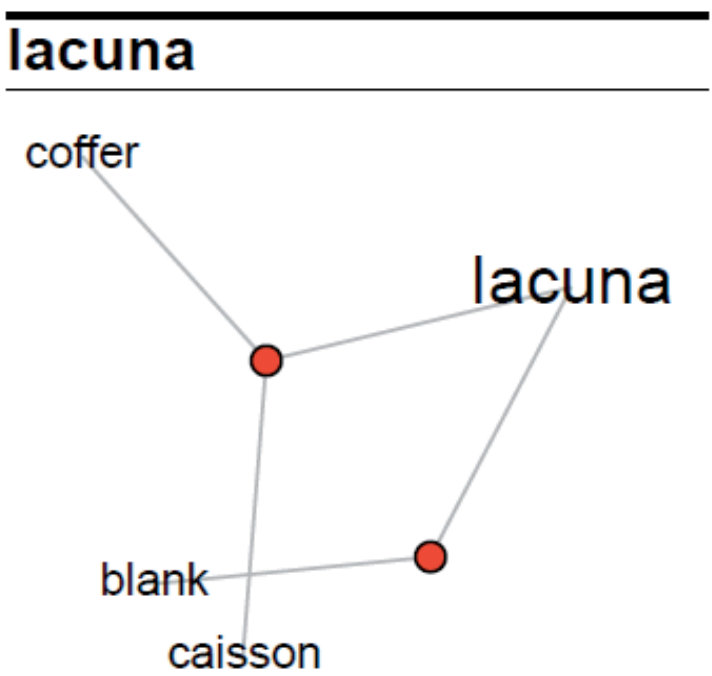
The cluster (i) Liquid of the lac-etymon. The Etymon "lacuna" is of Greek origin

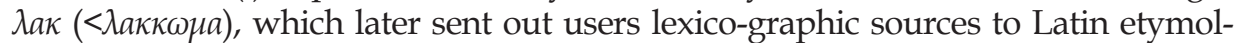
ogy lac (<lacūna) (Fowler, 1926, p. 313; Barnhart, 1995, p. 418). The fossilized allomorphs of lacuna are deceptively unlike each other in form, yet they are historically related - they are cognates. The morpheme $\lambda a k$ was borrowed from Greek, adapted and changed in Latin to $l a c(k)$-, then lacuna group had a consequence of systematic changes in the Old English period.

The cultural and linguistic specifics of one culture can correspond to the "zero equivalent" in another. The establishment and development of new terminology in terms of lacunae theory is a challenge worthy attention of the international linguistics. The aim of this article is to discuss and illustrate what was done by linguists to start a worldview of the linguistic terminology of lacunology.

The term lacunology consists of two morphemes, the first of which has a long etymological roots as that submitted in writing to the authentic references. Failure to submit the token gap in many dictionaries indicates a lack of understanding of this unit. The lacunae of linguistic and mental concepts used to be transferred from generation to generation, but some elements were vague, thus the translation resulted in zero equivalents. There are some lacunar elements that need to be interpreted in many words for lacunae are often called words with non-equivalent in one word or two.

Lacunarity, from the Latin word "lacuna" meaning "gap" or "lake" in the naïve worldview, is a specialized term to denote the result of reduction or elimination, zero equivalence. Mostly, researchers use the term "lacuna", or "gap", "emptiness", "hole" to define a gap as "blank, missing, missing a place in the text". The lacuna-

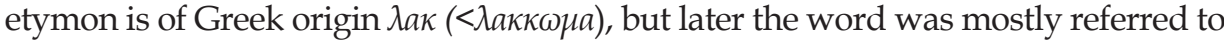
as of the Latin origin (<lacuna) (Webster, 1848, p. 644). The birth of the word lacuna is dated to the year 1663, when Latin lacūna meant hole or pit, from lacus (genitive lacūs) pond, lake (Barnhart, 1995, p. 418).

\section{THE LACONOLOGY IN TERMS OF LACUNOLOGISTS}

At first lacunae were only terms of translation studies and stylistics (Vinay, \& Darbelnet, 1958), later lacunology moved from the French-Canadian School (Paris/Montreal) to Russia, where lacunae were discussed by Yuriy Sorokin in many papers devoted to lacunology from 1981 to 2009 and Iryne Markovina in etnopsychological studies of lacunology (Russia) and by Igor Panasiuk (Germany) and other scientists (Sorokin, \& Markovina, 2010, p. 8). The lacunae-oriented research was done in the area of linguistics (Bikova, 1999), translation studies (Pym, 1993), advertising research (Grodzki, 2003), cultural studies (Zhelvis, 1979), contrastive linguistics (Strenin, 2004).

According to Iosif Sternin, the lacunarity and non-equivalent words are the most vivid manifestation of national specifics in culture and unique semantics of words of any language (Sternin, 2004, p. 21). I. Panasiuk defines lacunar elements as "a signal or a marker of presence of an intercultural or interlingual difference in the meaning and the starting point for the semantic assessment of an equivalence relation" (Pa- 
nasiuk, 2009, p. 44). Anna Ogarkova, Cristina Soriano and Caroline Lehr discovered that there are lacunae of emotions absent in other languages, such as toska in Russian, amae in Japanese, Schadenfreude in German, saudade in Portuguese, or przykro in Polish (Ogarkova, 2012, p. 255-256). The term "lacuna/gap" refers to the absence of a lexical item in the language while there is a concept in the conceptual sphere with zero verbalization. It is evident that in contrasting languages lacunae of culture make up the taxonomy of lacunae of the language, speech and cognition (the object of lacunology). The way lacunae are named in terms of lacunology is the linguistic "lacunicon". I. Sternin used to stress the fact of the mirror effect: lacuna in the local culture is non-equivalent element in the other culture (Sternin, 1989, p. 24; Sternin, 1989 p. 36). Vladimir Gak explained that lacunae/gaps are missing elements in the lexical system of the language, the lacunae are words, which seemed to be lacking in the contrasting language (i.e. ukr. kip yatok - en. boiling water) (Gak, 1977, p. 261). This researcher believes that gaps are concepts that exist in society but have different verbalization in languages. In the terminology of Vladimir Zhelvis we can say that the "lacuna/gap" is that which in some languages and cultures is represented by "isolation" in another, with no fixed equivalent expression' (Zhelvis, 1977, p. 136). The gaps/lacunae are implied inconsistencies in the contrasted languages in the conceptual, linguistic and emotive categories of the local cultures (Zhelvis, 1979, p. 194).

\section{THE CANADIAN SCHOOL OF LACUNOLOGY: TRANSLATION GAPS}

The linguists who dealt with translation difficulties and lacunae elimination were Jean Paul Vinay (1910-1999) and Jean Darbelnet (1904-1990). J. Darbelnet was born in Paris, studied at the Sorbonne, worked as a reader at the universities of Wales, Edinburgh and Manchester. In 1938-39 he moved to Canada, where he taught at McGill University from 1940 until 1946, setting up a three-year programme of night classes in translation.

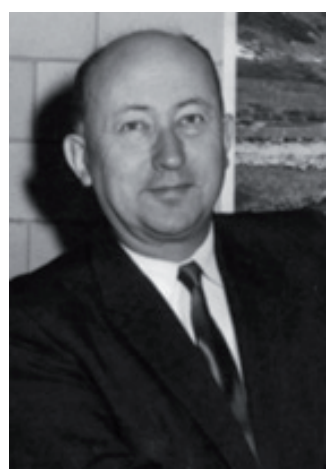

J. P. Vinay (1910-1999) was born in Paris and studied English at the Sorbonne before obtaining an MA in Phonetics and Philology from the University of London in 1937. He served with the French army in 1939-40 as a liaison officer with the British Expeditionary Forces. In 1946 he moved to Canada, where he taught at the University of Montréal as professor and head of the department of Linguistics and Translation. In addition to his work on translation he directed publication of the bilingual Canadian Dictionary in 1962 and became well-known through a television course Speaking French. In 1967 he moved to the University of Victoria in British Columbia. The translation gaps were described by J. P. Vinay and J. Darbelnet and their followers as lacunae traced as problems of translation.

We find the lacunae as defined by J. P. Vinay and J. Darbelnet in the Translation Studies Reader prepared by Lawrence Venuti and edited by Mona Baker, cf.: The 
translators may also notice gaps, or "lacunae", in the target language (TL) which must be filled by corresponding elements, so that the overall impression is the same for the two messages (Venuti, 2000, p. 84).

\section{LACUNAE IN TERMS OF ANTHONY PYM: LACUNAE AS LIMITS OF CULTURE}

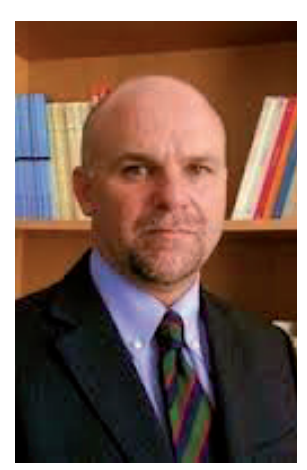

A. Pym has obvious impact on modern linguistics, translation and lacunology. The natural and directional equivalence in translation was his primary focus. He is famous for works in translation studies, the sociological approaches to cross-cultural communication. His many books and publications include Translation and Text Transfer (1992), Against Praise of Hybridity (2001), Method in Translation History (1998), Exploring translation theories (2010), see also the full list of publications.

This researcher stressed the possibility and importance of recognizing and conveying cultural lacunae; also, A. Pym realized the importance of translation as a mode of recognizing and conveying their uncertainty as "darkness" (Pym, 1993, p. 36-37).

Some social and cultural phenomena are lacking in different cultures. In an interview with A. Pym on translator history the famous linguist disseminated some suggestions on translation, the cultural specificity and enviable lacunae that occur in translating one culture into another. He believes there are lacunae and uncertain limits in cultures but that nevertheless everything can be translated. The result of the loss is a lacuna - blank space, gap, unclear element. Some elements (lacunae) are called "resist translation", "good markers of the substantiality" and "limits of a culture" (Pym, 1993, p. 27). The problem of limited or vague understanding as part of the source text can be solved by quite different translation strategies and solutions. There is always a limit to translations: something will be lost in translation.

\section{THE LACUNAE IN THE TERMS OF GULCHERA BIKOVA: THE WHITE SPOTS}

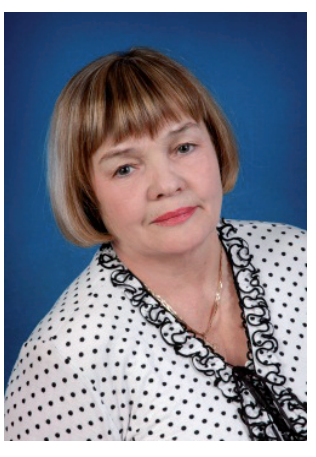

Gulchera Bikova (1950) is the well known Russian scientist who works in the sphere of the areal lacunology. Her thesis was devoted to lacunarity. Her monographs are devoted to lacunae: "The intralingual lacunarity in the system of the Russian Language" (1998), "The phenomenology of the lexical lacunarity" (2002), "The lacunarity as lexical category of systemology" (2005). Under the scientific guidance of prof. Zinaida Popova (Voronezh School of the Theoretical Linguistics) G. Bikova wrote on gaps and concepts, on the intralingual lacunarity, on "white spots" of the Russian semantic space, devoted her research to the problem of intralinguistic lacunarity, on lacunae of cognition and culture. The white spots are gaps 
in the language systems which are highlighted when comparing the languages and missing elements of culture.

\section{THE COGNITIVE MAPPING OF THE LINGUISTIC LACUNICON}

Mind mapping of the lacunicon has emerged attempting to establish equivalence between various lacunar concepts known as vague elements of culture (national specifics), lacunae in speech (speech lacunas), and lacunae in the language. This mind map reports that the results of an observation can be traced as a reference-based methodology of lacunology.

The Lacuna Theory has several Models of Lacunicon (Vague Elements of Culture, Lacunae in Speech, Lacunae in Language, Lacunae of Time and Gaps of Cognition). The mind map has several hierarchical clusters. The linguistic gap is a pause in syntagmatics (lacunae in speech), a linguistic gap in paradigmatics are empty places (grammatical, syntactical, phonetic and lexical lacunae). There is a lacuna of time (diachronic and synchronic regime) and gaps of cognition which include lacunae of experience, lack of the linguistic thesaurus and background knowledge.

The results of the cognitive mapping are discussed in given in the scheme mode below.

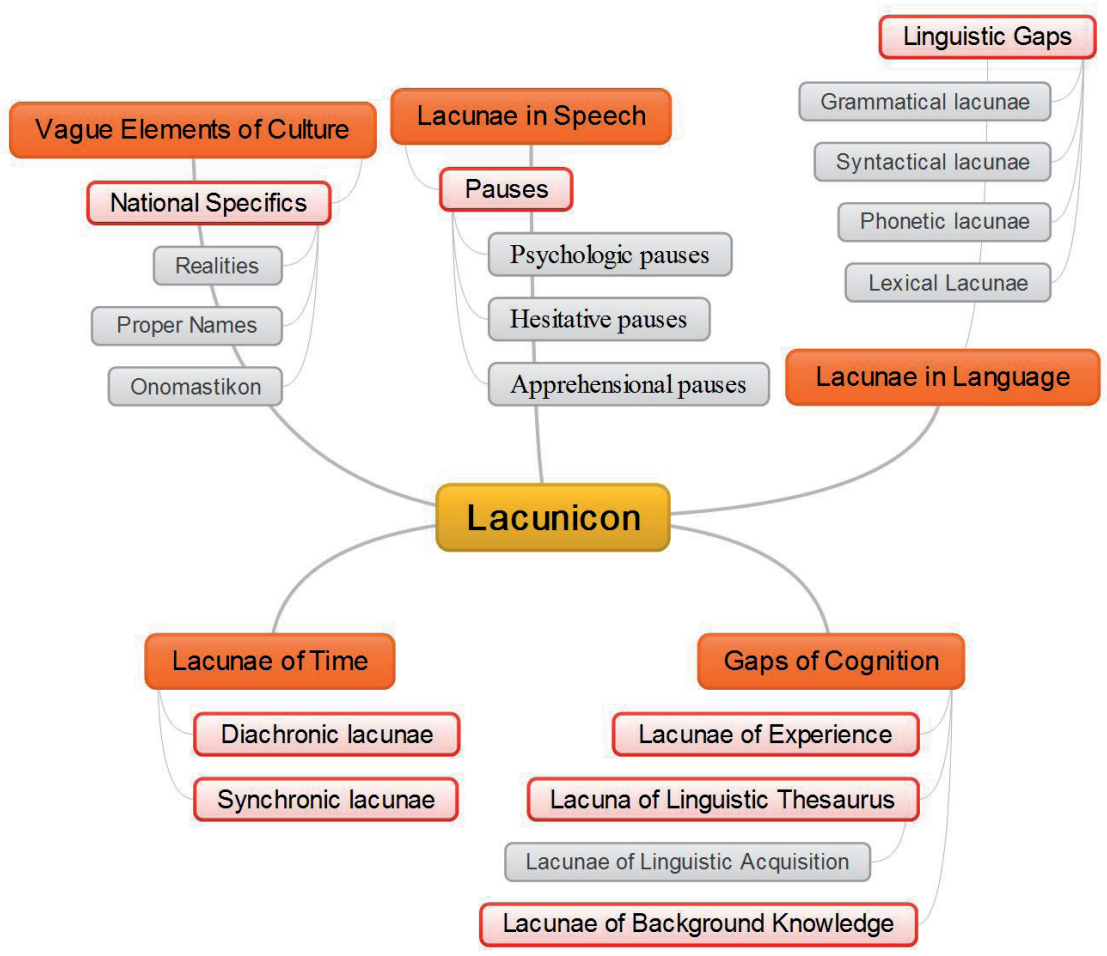

Fig. 2. The Lacunicon (paradigmatic, syntagmatic, temporal and cognitive vectors). 
Lacunae can be eliminated by either omission or shift (substitution, modulation or transposition). The omission is the "deletion of lacuna", "absence of translation" or putting the specific element in italics without translation (c.f. The Stylistique comparée du français et de l'anglais). To render lacuna or liquidate lacuna means two methods of translation, cf.: the vague element may be rendered by shift (i) (transposition, substitution or modulation) or (ii) by means of the omission technique. J. P. Vinay claimed that these principles actually founded the "Canadian School of translation" (Vinay, \& Darbelnet, 1958, p. 148).

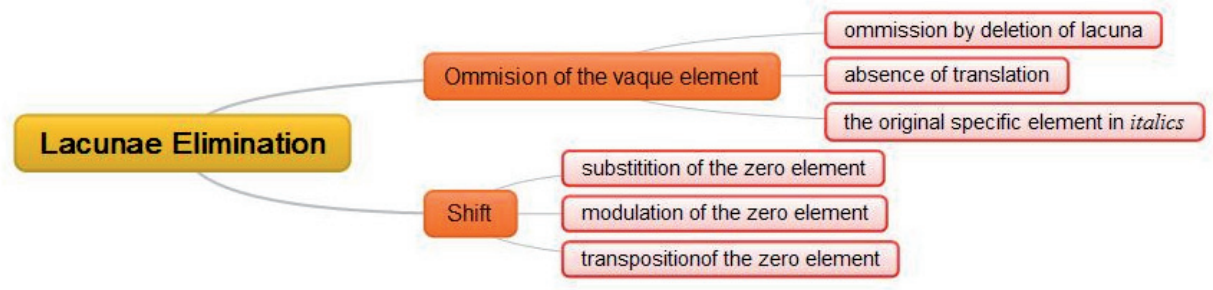

Fig. 3. The ways to deal with lacuna: omission vs shift.

The specifics of the social lacunae in terms of A. Pym can be rendered or some part of the original can be transmitted but the other part should be left in the commentary in the original with the footnote, not just translated. Some elements of the culture cannot be translated. These gaps, or empty spaces in translation, are called the cultural specifics that can be lost in translation. Referring to A. Pym's understanding of transcultural relations, there are three strategies for lacunae elimination: transpositions, substitutions or modulations to translate the textual lacunae (Pym, 1993, p. 34).

The lacunae (gaps) are often associated with the problem of translation difficulties that can be attributed to a lack of room not in the target culture, but to lacunae in the source culture. The "PRO constituents" are someone or something (Warndhaugh, 1972, p. 119). There are some specific elements in the national picture of the world that cannot correspond to one-word notion, the lexical equivalent or have some differences compared to the other language. The phenomenon has been called "lacunarity". The linguistic lacunicon embraces the "cross-linguistic lacunarity", "cognitive lacunarity" and the "proper linguistic lacunarity" (lacunae of the language and speech). The term "lacuna' corresponds to the term "gap" in the modern linguistics. Further research will be directed towards linguistic lacunicon, its terms and taxonomies.

The new science has been designed: (i) to deal with lacunae of the different linguistic levels forming paradigmatic and syntagmatic clusters of the category of lacunarity, (ii) to differentiate between diachronic and synchronic exteriorization of lacunae and (iii) in terms of lacunae elimination to show the ways how to compensate "zero items" which used to be qualified as the interlinguistic mirror of "cultural specifics". Astrid Ertelt-Vieth stressed the cultural specifics: The Russians tend to bring the best clothes to the journey, while the Germans prefer comfortable clothes 
(Ertelt-Vieth, 2005, p. 264). Thus the cultural lacunae can cause the secondary items in communication (known also as misunderstanding) leading to the communicative failures (Humphreys-Jones 1987, pp. 25-33).

\section{CONCLUSION}

Difficulties in translation are caused by cultural, cognitive and interlinguistic factors. Some specific words or concepts missing in the contrasted languages, cultures and cognition are considered to be the limits of culture, lacunae or gaps. The lacunae theory has to find proper methods to eliminate lacunae, thus rendering the ethos of the specific cultural elements from one language into another. These ethnic lacunae are part of the national consciousness; they are associative, implicit phenomena that require thoughtful interpretation.

At present, lacunae theory is often associated with translation studies where lacunae are interpreted as "translation gaps" caused by irrelevance in the target text of translation where the specific or vague information is often substituted by "zero equivalents". The ways to eliminate lacunae are associated with such terms as the non adequacy of translation, methods to hide lacunae are described by the terminological such synonymic notions as: (i) 'naturalizing ("domestication") and (ii) "estranging" ("foreignization"). Mostly, terms of lacunarity are adherent to terms "misunderstanding", "implicity", "change" and "reduction".

\section{REFERENCES}

Barnhart, R. K. (1995). The Barnhart concise dictionary of etymology. New York: HarperCollins Publishers.

Bikova, G.V. (1999). The lacunarity as a category of the lexical systemology. Communication culture and its formationtion, 6, 60-63.

Bikova G. (n.d.). Evenki of Amur. Retrieved January 3, 2013, from http://www.evenki.info/.01.2013.

Bikova bio (n.d.). Retrieved January 3, 2013 from http://www.bgpu.ru/Bikova/data/bikova_bio/enciclopedia/slav.pdf.

Biography: Anthony Pym (n.d.). Retrieved January 3, 2013, from http://www.jostrans.org/issue01/ cv_pym.php.

Ertelt-Vieth, A. (2005). Interkulturelle Kommunikation und kultureller Wandel [Intercultural communication and cultural change]. Tubingen Gunter: Narr Verlag.

Firth, K., \& Ballyn, S. (Eds.). (1993). Australia in Barcelona. Barcelona: Universitat de Barcelona.

Fowler, H.W. (1926). A Dictionary of Modern English Usage. London: Oxford at the Clarendon Press.

Gak, V. (1977). The Contrasting Lexicology. The work was performed on the material of the French and Russian languages. Moscow: International relations.

Grodzki, E. (2003). Using Lacuna Theory to Detect Cultural Differences in American and German Automotive Advertising. Frankfurt am Main: Peter Lang.

Holger Kuße (2012) Bekannte Modelle und Studien (Theorie der Kulturdimensionen), Interkulturelle Kommunikation. Retrieved from http://tu-dresden.de/die_tu_dresden/fakultaeten/fakultaet_sprach_ literatur_und_kulturwissenschaften/slavistik/studium/unterrichtsmat/mat_ss2012/ikk.

Humphreys- Jones, C. (1987). The structure of misunderstandings. Reilly. In: G. Ronan (Ed.), Communicative failure in dialogue and discourse (pp. 25-33). Amsterdam: North-Holland: Elsevier publishers.

Molzbichler D. (2004) Kulturen in konflikt? Retrieved from http://www.alois-mock.at/download/Diss_ Molzbichler.pdf.

Nikiforova, A. S., Kuryleva L. A. (n.d.). Political Media Discourse within the Context of Intercultural Communication. Retrieved January 3, 2013, from http://psr.kangnam.ac.kr/psr_bk_iss/vol12/03_02. pdf. 
Ogarkova A., Soriano C., Lehr C. (n.d.). Naming Feeling: Exploring the Equivalence of Emotion Terms in Five European Languages. Retrieved January 9, 2013, from http://www.affective-sciences.org/ system/files/biblio/Ogarkova,\%20Soriano\%20and\%20Lehr_2012_Naming\%20Feeling_Lodz.pdf.

Online Etymology dictionary. Retrieved January 10, 2013, from http://www.etymonline.com/index. php?allowed_in_frame $=0 \&$ search $=$ Lacedaemonian $+\&$ searchmode $=$ none.

Panasiuk, I. Schröder H. (2007). Lakunen-Theorie: Ethnopsycholinguistische Aspekte der Sprache-und Kulturforschung [The Lacunae Theory: Psycholinguistic aspects of ethnic Language and Cultural Research], The issues on Psycholinguistics, 6, 219-224.

Panasiuk, I. (2009). Definition of the Lacuna Phenomenon in the Theory of Translation, The issues on psycholinguistics, 3 (10), 42-46.

Pym, A. (1993) Lacunae and uncertain limits in Australian culture, with suggestions on their translation into Spanish. Retrieved from http://usuaris.tinet.cat/apym/on-line/australia/1993_lacunae.pdf.

Pym, A. (1992a). Translation and Text Transfer. An essay on the Principles of Intercultural Communication. Frankfurt am Mein, Berlin, Bern, New York, Paris, Vienna: Peter Lang.

Pym, A. (1993b). Lacunae and uncertain limits in Lacunae and uncertain limits in Australian culture, with suggestions on their translation into Spanish. In: K. Firth, \& S. Ballyn (Eds.), Australia in Barcelona (pp. 27-37). Barcelona: Universitat de Barcelona.

Pym, A. (1998c). Method in Translation History. Manchester: St. Jerome.

Pym, A. (2001d). Against Praise of Hybridity. Across Languages and Cultures, 2(2), 195-206.

Pym, A. (2010) Interview on current issues in Translation Studies. Retrieved from http:// usuaris.tinet. cat/apym/on-line/research_methods/2010_interview.pdf.

Pym, A. (n.d.). Natural and directional equivalence in theories of translation. Retrieved January 3, 2013, from http:/ / www.ualberta.ca/ ivashkiv/translation/PYM\%20on\%20equivalence.pdf.

Pym, A. (n.d.). List of publications. Retrieved January 3, 2013, from http:/ / usuaris.tinet.cat/apym/publications/publications.html.

Visual Thesaurus. Retrieved January 10, 2013, from http:/ /www.visualthesaurus.com.

Ronan, G. (Ed.). (1987). Communicative failure in dialogue and discourse. Amsterdam: North-Holland: Elsevier publishers.

Walker, S. E. C., \& Cavanagh W. G. (1995). Sparta in Laconia. Proceedings of the $19^{\text {th }}$ British Museum Classical Colloquium held with the British School at Athens and King`s and University Colleges. London: British School at Athens.

Pomeroy, S. B., Burstein, M. S., Donlan, W., \& Roberts, J.T. (1998). Ancient Greece: A Political, Social, and Cultural History. Oxford: Oxford University Press.

Schröder, H. (1995). "Lacunae" and the Covert Problems of Understanding Texts from Foreign Cultures, Lacunology - Studies in Intercultural Communication. Vaasa: Vaasan Yliopiston Julkaisuja, 10-25.

Sorokin, Y.A., Markovina I. Y. (2010). Culture and text. The introduction to the lacunology. Moscow: GEOTAR-Media.

Sternin, I.A. (1989). (in co-authorship with K. Fleckenstein) Sketches on contrastive lexicology and phraseology. Halle: Martin-Luther-University of Halle-Wittenberg.

Sternin, I.A. (2004). Contrastive linguistics. The problems of theory and methodology of investigation. Voronezh: Istoki publishers.

The American heritage college dictionary (1993). 3rd ed. Boston. New York: Houghton Mifflin Company.

Venuti, L., Baker, M. (2000). The Translation Studies Reader. London and New York: Routledge, Taylor \& Francis group.

Vinay, J. P. and Darbelnet, J. (1958). Stylistique comparée du français et de l'anglais: méthode de traduction. Nouvelle édition revue et corrigée. Paris: Didier.

Wardhaugh, R. (1972). Introduction to linguistics. New York: McGraw-Hill.

Webster, N.; Goodrich, Chauncey A.; Porter, N. (1848). Webster's New World Dictionary of the American language. Springfield: Mass G. and C. Merriam.

Neufeldt, V. E. (1988). Webster's New World Dictionary of American English (Ed.), Cleveland \& New York: Simon \& Schuster.

Willem, D. B. Laconian Studies (1954). Amsterdam: North-Holland publishing.

Zhelvis, V.I. (1977). The issue on the character of the of English-Russian lacunae. The Research on Problems of the Speech Communication (pp. 136-146), Moscow: Nauka publishers.

Zhelvis, V.I., Markovina, I.Y. (1979). The experience of systematization of English-Russian lacunae. The Research on Problems of the Speech Communication (pp. 136-146). Moscow: Nauka publishers. 